INTERNATIONAL MONETARY FUND
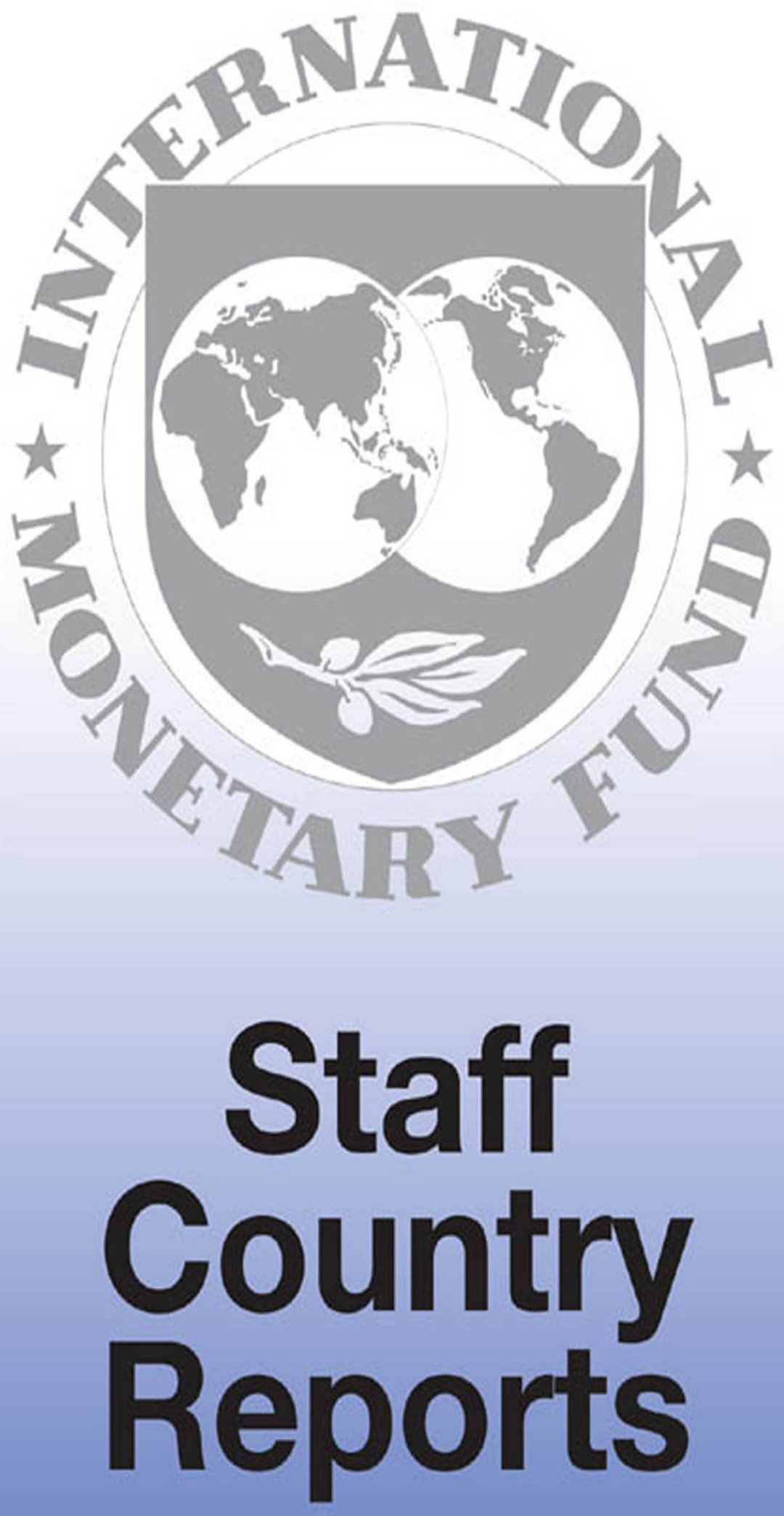


\section{Jordan: Selected Issues}

This selected issues paper on Jordan was prepared by a staff team of the International Monetary Fund as background documentation for the periodic consultation with the member country. It is based on the information available at the time it was completed on March 26, 2012. The views expressed in this document are those of the staff team and do not necessarily reflect the views of the government of Jordan or the Executive Board of the IMF.

The policy of publication of staff reports and other documents by the IMF allows for the deletion of market-sensitive information.

Copies of this report are available to the public from

International Monetary Fund • Publication Services

$70019^{\text {th }}$ Street, N.W. • Washington, D.C. 20431

Telephone: (202) 623-7430 • Telefax: (202) 623-7201

E-mail: publications@imf.org Internet: http://www.imf.org

\section{International Monetary Fund Washington, D.C.}


This page intentionally left blank

CInternational Monetary Fund. Not for Redistribution 


\section{INTERNATIONAL MONETARY FUND}

\section{JORDAN}

\section{Selected Issues}

Prepared by Moataz El-Said, Yasser Abdih, Annette Kyobe, Mehdi Raissi, Agustin Roitman, and Hirut Wolde (all MCD), Anna Ter-Martirosyan, and Nkunde Mwase (both SPR)

Approved by the Middle East and Central Asia Department

March 26, 2012

Content

I. Energy Subsidies: Fiscally Burdensome and Inequitable

Figures

1. Fiscal Cost of Energy Price Subsidies $\underline{3}$

2. Jordan Domestic and International Diesel Prices ..........................................................

3. Expenditure Shares of Energy Products by Welfare Level ................................................ 4

4. Share of Benefit from Energy Subsidies .....................................................................

II. Oil Prices and the Jordanian Economy ……………....................................................

Figures

1. Oil Imports and Oil Prices

2. External Income and its Composition.......................................................................

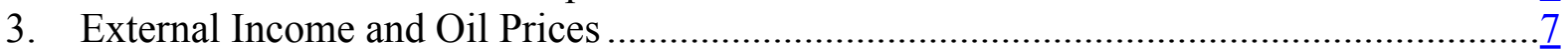

4. Jordan's Exports to GCC and Oil Prices ………….........................................................

III. Assessing Reserve Adequacy in Jordan .................................................................

Figures

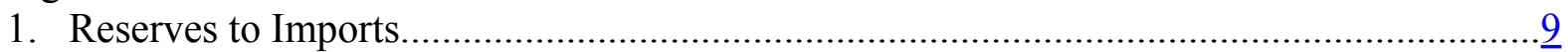

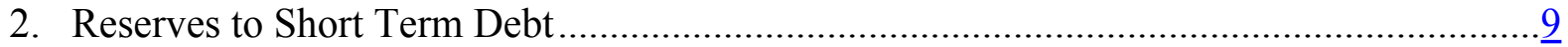

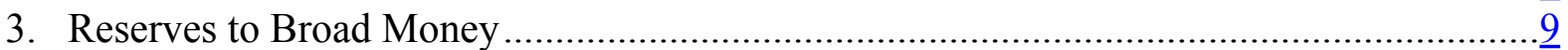

4. Reserves to Short Term Debt + Current Account Deficit....................................................

5. Model-Based Optimal Level of Reserves ................................................................

6. Reserves Against Risk-Weighted Metric ........................................................................

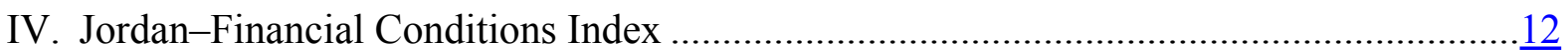

Figure

1. Jordan: Financial Conditions Index 
V. Drivers of Growth in Jordan $\underline{14}$ Figures

1. Real GDP Growth Rate in Jordan .14

2. Sector Shares of GDP by Decade $\underline{14}$

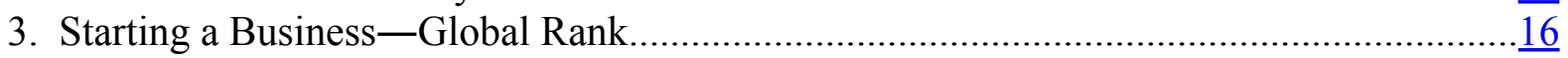

4. Getting Credit—Global Rank ……….....................................................................

Tables

1. Sectoral Contribution to Real Growth in Percentage Points............................................ 15

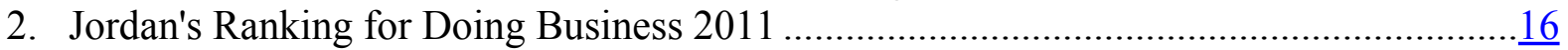

VI. Fiscal and Debt Implications of Mega Projects ............................................................

Table

1. Jordan: Consolidated Impact of Megaprojects on Central Government............................19

VII. The Employment Challenge Facing Jordan.................................................................. Figures

1. Unemployment Rates by Region

2. Employment-to-Working Age Population Ratios and Labor Force

Participation Rates By Region .$\underline{22}$

Table

1. Growth Required to Absorb New Labor Force Entrants and Currently Unemployed .......23

VIII. Taking Stock of Public Investment Efficiency, Capital Accumulation and Total Factor Productivity in Jordan

Figures

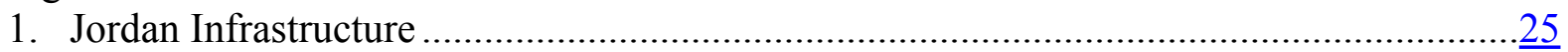

2. PIMI Overall Index: Decomposition by Sub-Index..................................................

3. PIMI Index and its Sub-Components: Selected Countries in MENA...............................27

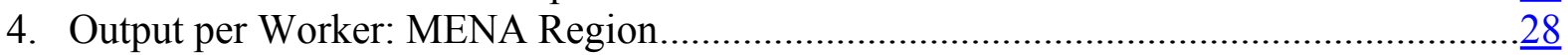

Table

1. Decomposition of Output Per Worker, 1992-2008 


\section{ENERGY SUBSIDIES: FisCALLY BURDENSOME AND INEQUITABLE ${ }^{1}$}

The cost of energy price subsidies represented close to 6 percent of GDP in 2011. Given their universal (untargeted) nature, these subsidies disproportionately benefit rich households as they account for a relatively large share of total energy consumption. Leakage of benefits to higher income groups makes energy price subsidies an extremely costly mechanism for the provision of social assistance to lower-income households.

\section{Amid heightened social and political tensions in the region, energy price} subsidies increased substantially in Jordan during 2011. Energy price subsidies are expected to increase from about $1 \frac{1 / 3}{3}$ percent of GDP in 2010 to nearly $6 \frac{1}{4}$ percent of GDP in 2011 (Figure 1). ${ }^{2}$ This is due to the impact of higher international prices on existing liquefied petroleum gas (LPG) subsidy schemes; the authorities' decision in early 2011 to freeze fuel prices and stop implementing the monthly automatic adjustment pricing mechanism adopted in 2008 (Figure 2); and frequent disruptions of gas supply from Egypt. ${ }^{3}$

Figure 1: Fiscal Cost of Energy Price Subsidies

(Percent of GDP)

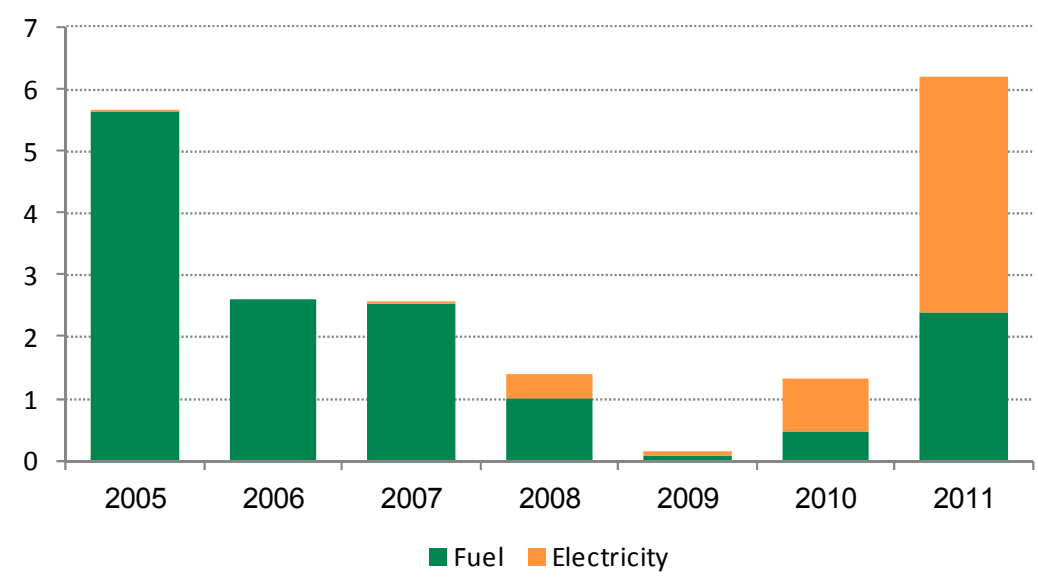

Source: IMF staff estimates based on data provided by authorities.

\footnotetext{
${ }^{1}$ Prepared by Moataz El-Said.

${ }^{2}$ The electricity subsidy does not appear in the central government budget. It is calculated as the difference between Jordan's National Electric Power Company (NEPCO) cost-recovery price and the wholesale price charged to distributors. It increased from JD 161 million in 2010 to an estimated JD 1.1 billion in 2011 , equivalent to 3.8 percent of GDP.

${ }^{3}$ The pipeline transporting Egypt's natural gas to Israel and Jordan has been damaged by explosions thirteen times since January 2011. The gas is mainly used for electricity generation, forcing Jordan's NEPCO to use more costly imported fuel oil during the extensive periods of interrupted gas supply. As a consequence, NEPCO's debt increased from JD 453 million at end-2010 to an estimated JD 1.3 billion by end- 2011 .
} 


\section{Energy price subsidies pose a serious fiscal risk in the present context of} increasing and volatile international prices. Jordan is a net oil importer and a highly energy-dependent country. If international prices continue their upward trend, keeping domestic prices unchanged could result in subsidies increasing to 18 percent of GDP by 2014. This would require a major fiscal adjustment, including substantial reductions in higher-priority public spending (e.g., on education, health, and public infrastructure).

Figure 2. Jordan Domestic and International Diesel Prices (In US cents per liter)

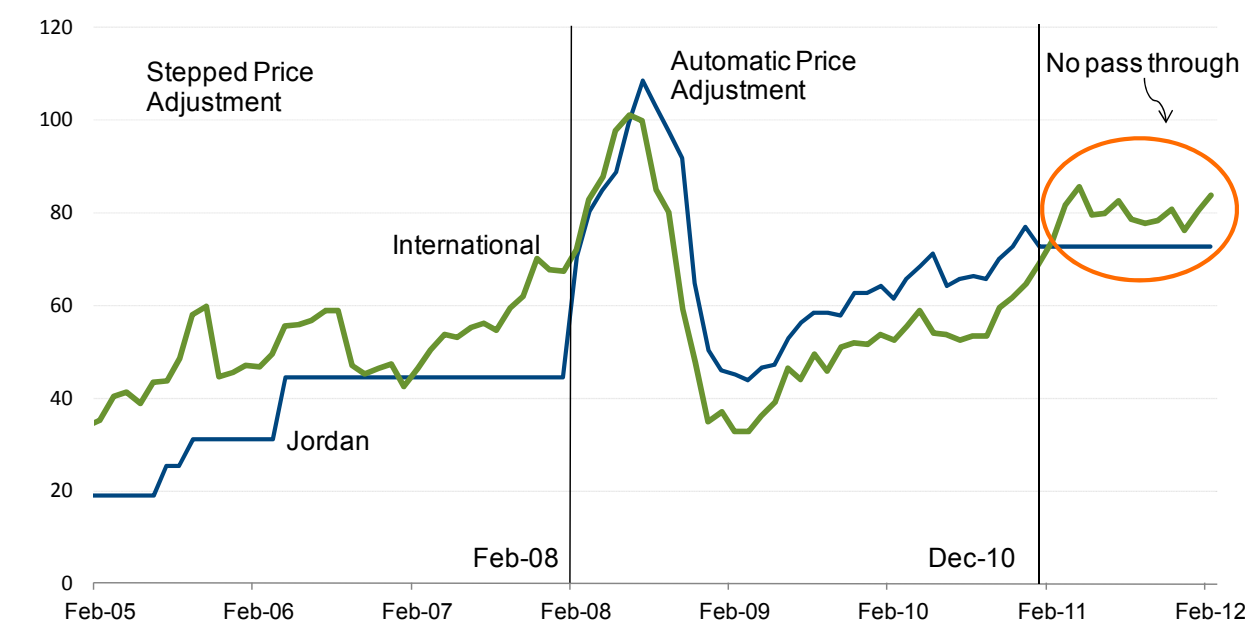

Source: Jordan Ministry of Energy and Mineral Resources, and the US Energy Information Administration.

\section{Existing universal (untargeted) energy price subsidies disproportionately benefit}

the rich, who account for a relatively high share of national energy consumption. Jordanian households allocate a substantial proportion of their budget to energy consumption. Expenditures on energy account on average for around 10 percent of total household consumption, with gasoline expenditure accounting for the highest share followed by electricity and LPG (Figure 3).

Figure 3. Expenditure Shares of Energy Products by Welfare Level

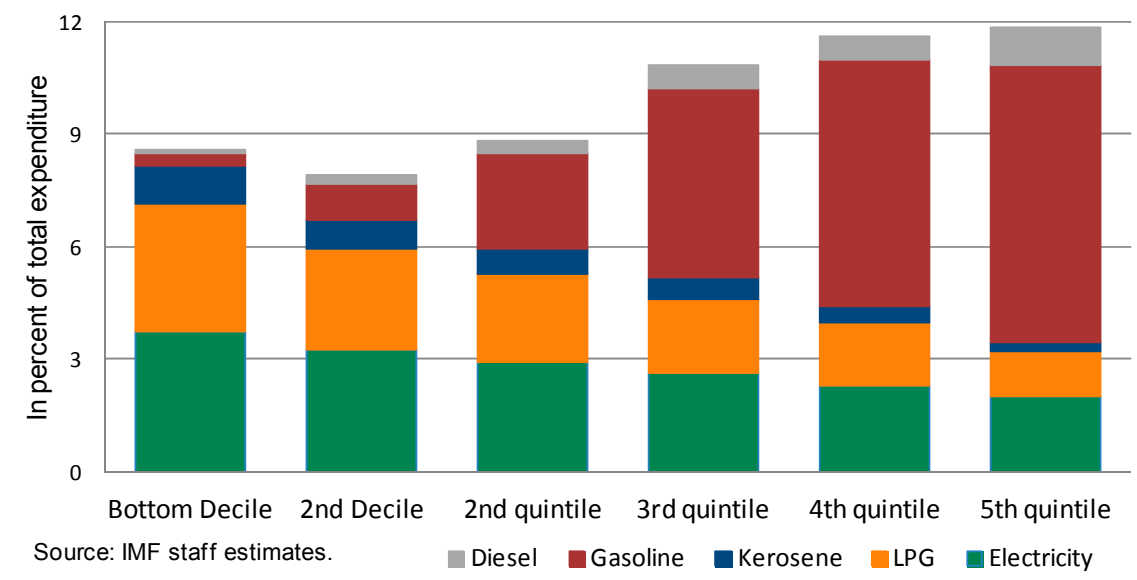


4. Benefits from energy subsidies are pro-rich. A very large share of the benefits from price subsidies is captured by higher-income households. Overall, the richest one-fifth (quintile) of households receives over 25 percent more in subsidies than the poorest one-fifth of households. The leakage of subsidy benefits to rich households is most pronounced in the cases of gasoline and diesel subsidies (Figure 4), where the richest one-fifth of households receives nearly $6^{1 / 2}\left(2^{1 / 2}\right)$ times more in gasoline (diesel) subsidies than the poorest one-fifth. Hence, benefits from energy subsidies are distributed inequitably among households.

\section{The substantial leakage of subsidy benefits to higher-income groups makes} energy price subsidies an extremely costly mechanism for the provision of social assistance to lower-income households. Every dinar transferred to the bottom two income quintiles through gasoline subsidies costs the budget about JD 5 (the bottom two quintiles' share in gasoline subsidies is around 20 percent-Figure 4). A simple cash distribution of these benefits to all households would have been less costly and more effective in assisting the poor. This inefficient and inequitable distribution of energy subsidies is not surprising; almost any universal consumption subsidy disproportionately benefits the rich since they, by definition, account for a relatively higher share of total energy consumption. Well targeted safety net programs can substantially reduce this leakage of benefits to higher income groups, and help protect the poorest households at much lower fiscal cost.

Figure 4. Share of Benefit from Energy Subsidies (Percent of Total Subsidies Accruing to Income Groups)

Gasoline

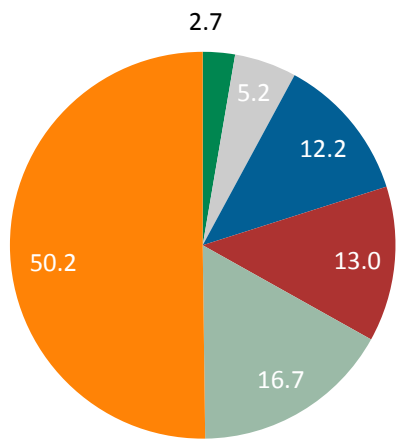

Diesel

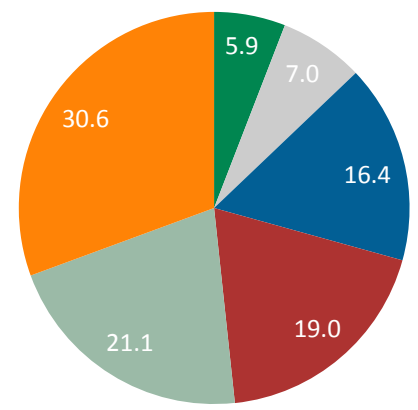

Source: IMF staff estimates based on information available in the 2008 Household Survey for Jordan. 


\section{OIl Prices ANd The Jordanian EconomY ${ }^{1}$}

Spillovers from the GCC to Jordan in the form of foreign direct investment (FDI), remittances, and general government transfers drive the real GDP of the country in the long run, and at the same time mitigate the negative impact of commodity price shocks on its growth dynamics.

1. The macroeconomic situation in Jordan is closely tied to that of other countries in the Middle East. Remittances from Jordanians working in other states, especially in the Gulf Cooperation Council (GCC) countries, are an important source of national income, equivalent to 15-20 percent of GDP. The Persian Gulf region is also the primary destination for Jordanian exports and in turn supplies most of its energy requirements. Additionally, the country receives substantial grants and foreign direct investments from other countries in the region, most notably from the GCC.

\section{As a result of these linkages, demand-driven oil price booms have two opposing} effects on Jordan's GDP: one of them direct and negative and the other indirect and positive. The direct negative effect occurs through the increase in import costs (Figure 1), while the indirect positive effect arises as a result of larger inflows of external income- the sum of foreign direct investment, remittances, and grants-from the region (Figures 2 and 3), higher phosphate export receipts (since different commodity prices are highly correlated), and higher regional demand for Jordanian exports due to favorable macroeconomic conditions in oil-exporting economies aided by oil hikes (Figure 4). It is estimated that a 10 percent demand-driven increase in the price of oil raises the GDP of Jordan by about 2.5 percent after 10 quarters. ${ }^{2}$ This finding shows that the indirect positive effects of oil price booms more than compensate for their direct negative impact as long as the external income inflows from the oil-exporting economies are maintained.

\section{The persistence of external income flows to Jordan from the GCC countries and} other oil exporters partly depends on the ability of the latter group to keep producing oil in the long run, as well as on the stability of oil revenue-to-GDP ratios in these economies over a prolonged period. For major oil exporting countries, many of which commenced oil extraction and exports at the beginning of the 20th Century, the reserve-to-extraction ratio indicates that they are capable of producing for many more decades even in the absence of new oil field discoveries or major advances in oil exploration and extraction technologies. As a result, external income flows to Jordan are not likely to disappear in the foreseeable future, and so their effects on long-run output and economic growth will continue to be substantial.

\footnotetext{
${ }^{1}$ Prepared by Mehdi Raissi.

${ }^{2}$ For additional details, see Mohaddes and Raissi (2011).
} 
4. From a policy perspective, macroeconomic and structural policies in Jordan should be conducted in such a way that the vulnerability of the country to sudden stops or reversals of external income flows is reduced. Change in the composition of external income flows towards foreign direct investment and a diversified export base, and away from general government transfers (as witnessed in recent history, see Figure 3), could help to generate income in the future. This chapter focuses on Jordan, but the analysis can of course also be extended to any oil-importing country in the region with strong ties to the GCC.

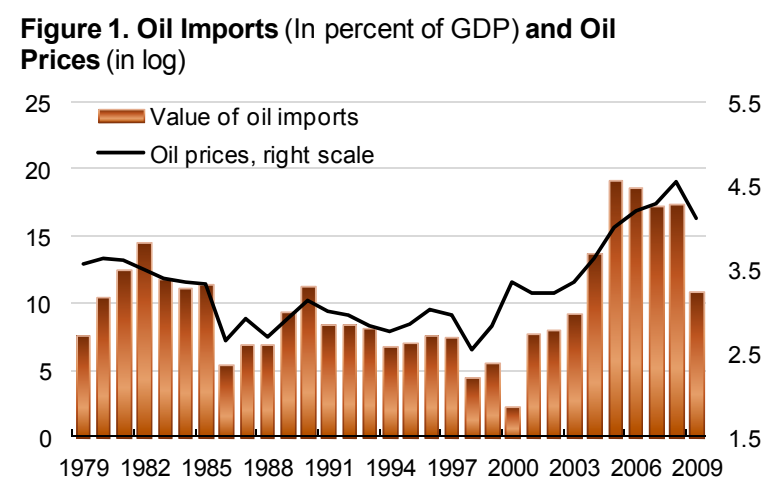

Sources: Authors' construction based on data from the IMF and UN Comtrade.

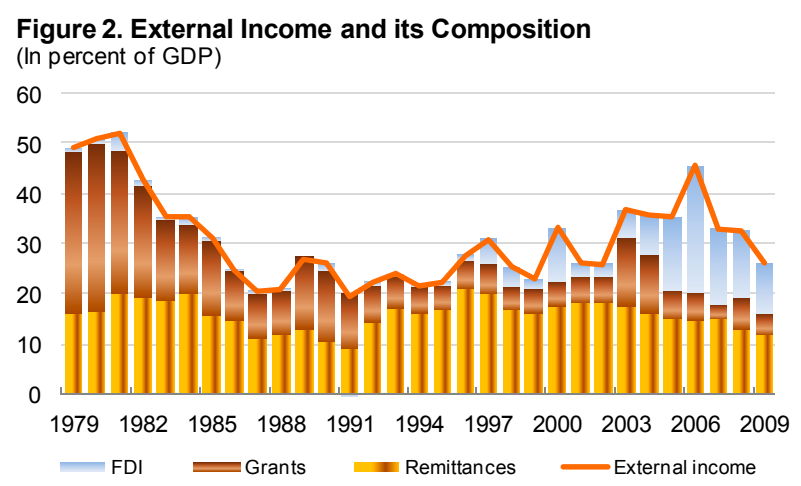

Source: Authors' construction based on data from the IMF.

Figure 4. Jordan's Exports to GCC and Oil Prices (in log level)

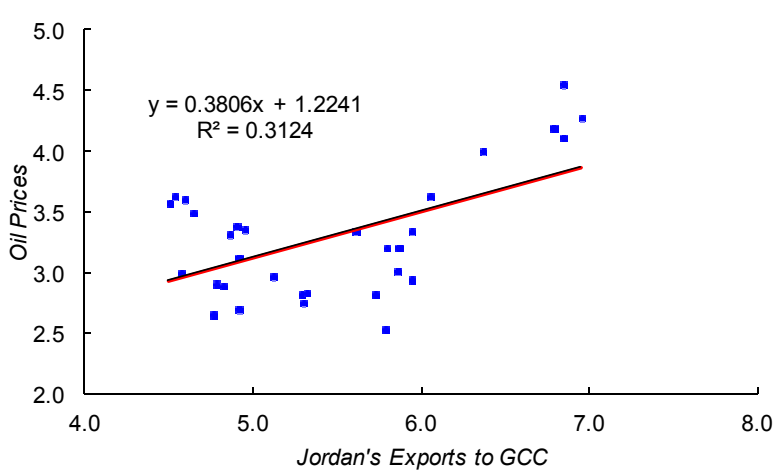

Source: IMF staff estimates based on data from the IMF.

\section{Reference}

Mohaddes, K. and M. Raissi, 2011, "Oil Prices, External Income, and Growth: Lessons from Jordan,” IMF Working Paper 11/291 (Washington: International Monetary Fund). 


\section{ASSESSING RESERVE ADEQUACY IN JORDAN ${ }^{1}$}

This chapter analyses the adequacy of international reserves in Jordan using three alternative methodologies: i) the traditional rules of thumb; ii) a reserve optimizing model; and iii) a risk-weighted metric recently developed by the IMF. ${ }^{2}$ The empirical results show that Jordan's actual reserve levels are higher than the minimum suggested by all these approaches.

\section{A. Introduction}

1. Jordan is a small open economy with close trade/financial linkages with the rest of the world. The country is highly dependent on remittances, grants and foreign direct investment inflows, and at the same time is very susceptible to commodity price shocks and regional/global economic conditions. Given that any sudden stop or reversal of capital/current inflows could expose Jordan to significant risks, holding an adequate level of international reserves is essential for the country to reduce its vulnerability to these disturbances and to support the pegged exchange rate. However, there is little consensus on what constitutes an adequate level of reserves from a precautionary perspective. The traditional rule of thumb measures are narrowly based and often provide conflicting signals, the model-based approaches are constrained to stylized modeling assumptions and calibrations, and reserve regressions suffer from simultaneity problems while inferring optimization from observed data. This chapter uses different methodologies to form as complete a picture as possible by relying on the advantages of each approach.

\section{B. Traditional Measures}

\section{Jordan's international reserve coverage has been comfortable in recent years,} based on traditional reserve adequacy metrics (such as import cover, short-term debt, broad money, and combination measures).

- Import cover, which is generally applied to countries where shocks arise from the current account, is often seen as a measure of the number of months imports can be sustained should all inflows cease. As shown in Figure 1, the often-used 3-months of imports cover is exceeded by a wide margin by Jordan, especially in recent years.

- Short-term debt (STD) is an indicator of crisis risk for market access countries such as Jordan. The "Greenspan-Guidotti" rule proposes a 100 percent cover for public and private external debt maturing over the next 12 months. As can be seen from Figure 2, Jordan has had enough reserves to provide such a cover since the 1988-89 crisis.

\footnotetext{
${ }^{1}$ Prepared by Mehdi Raissi.

${ }^{2}$ See IMF (2011), Assessing Reserve Adequacy, http://www.imf.org/external/np/pp/eng/2011/021411b.pdf
} 
- Reserves to broad money is usually intended to capture the risk of capital flight, given that many recent capital account crises have been accompanied by outflows of domestic residents' deposits. It may also be seen as a measure of potential need for bank support in or after a crisis. Figure 3 shows that Jordan meets the 20 percent benchmark comfortably.

- Finally, combination metrics-such as an expanded Greenspan-Guidotti rule of STD plus the current account deficit-seek to reflect a broader range of sources of risk. Figure 4 shows that Jordan fell short of this rule at times when the current account deficit was high.

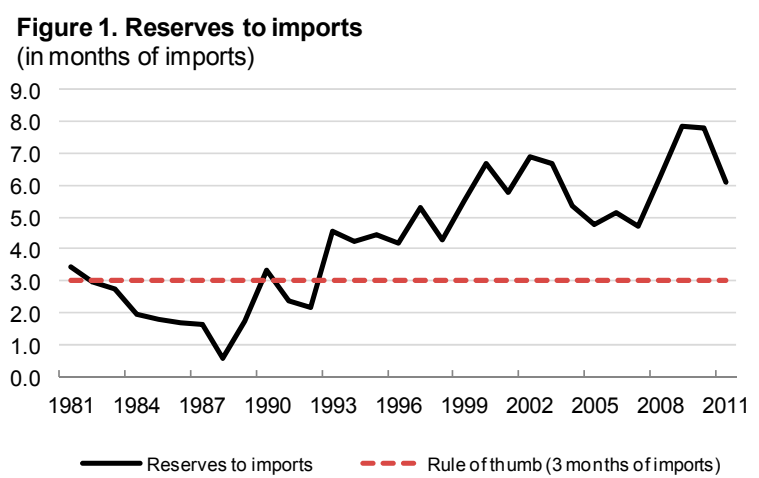

Figure 3. Reserves to broad money

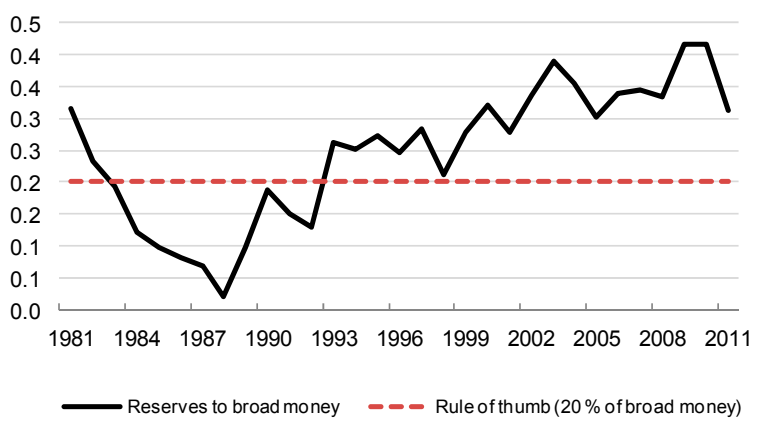

Source: IMF staff calculations.

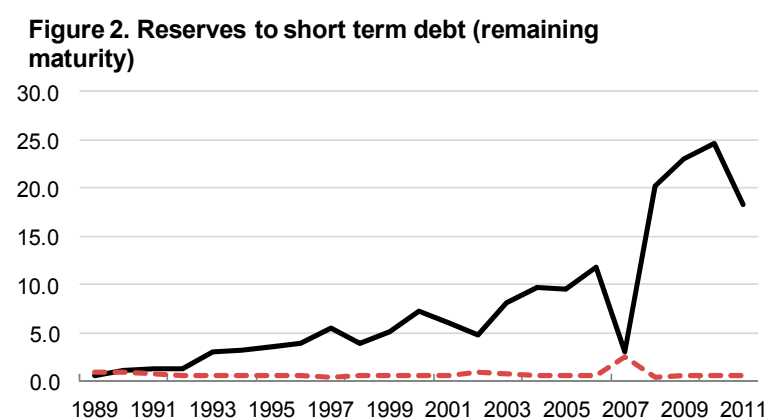

Reserves to short term debt (remaining maturity)

- - Greenspan-Guidotti rule ( $100 \%$ coverage)

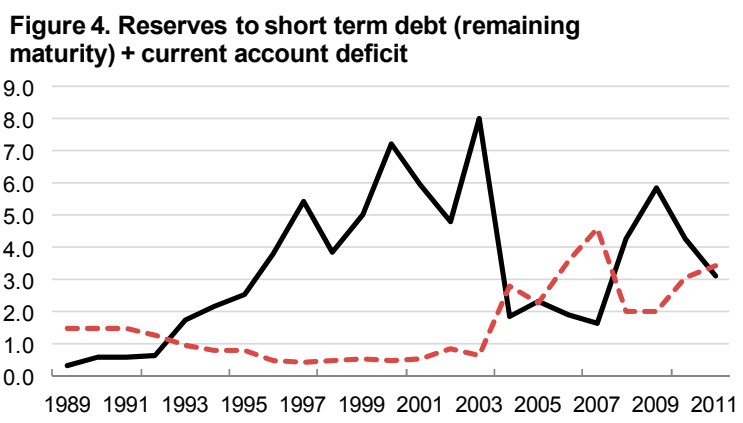

Reserves to short term debt (remaining maturity) + current account deficit - - Expanded Greenspan-Guidotti rule (100\% coverage)

\section{The Reserve Optimizing Model of Jeanne and Ranciere (2006)}

\section{This model describes reserve accumulation in a small open economy as an}

optimization problem in which risk-averse policy makers choose the level of reserves to provide optimal insurance against a sudden stop in consumption given the costs of holding reserves. When a sudden stop occurs, external debt cannot be rolled over and output falls below its long-run growth path. A buffer stock of reserves can mitigate the fall in output and smooth consumption. However, there is a cost to holding reserves as they yield a lower return than other assets in the economy. In this model the optimal level of reserves is determined by the size and probability of the sudden stop, the potential loss in output and consumption, the opportunity cost of holding reserves, and the degree of risk aversion. 
4. Based on this model, the optimal level of reserves for Jordan is calibrated to be much below the actual holdings post the $1988-89$ balance of payments crisis. As seen in Figure 5, actual reserve levels in most cases exceed those spelled out by Jeanne and Ranciere model, especially in the last decade.

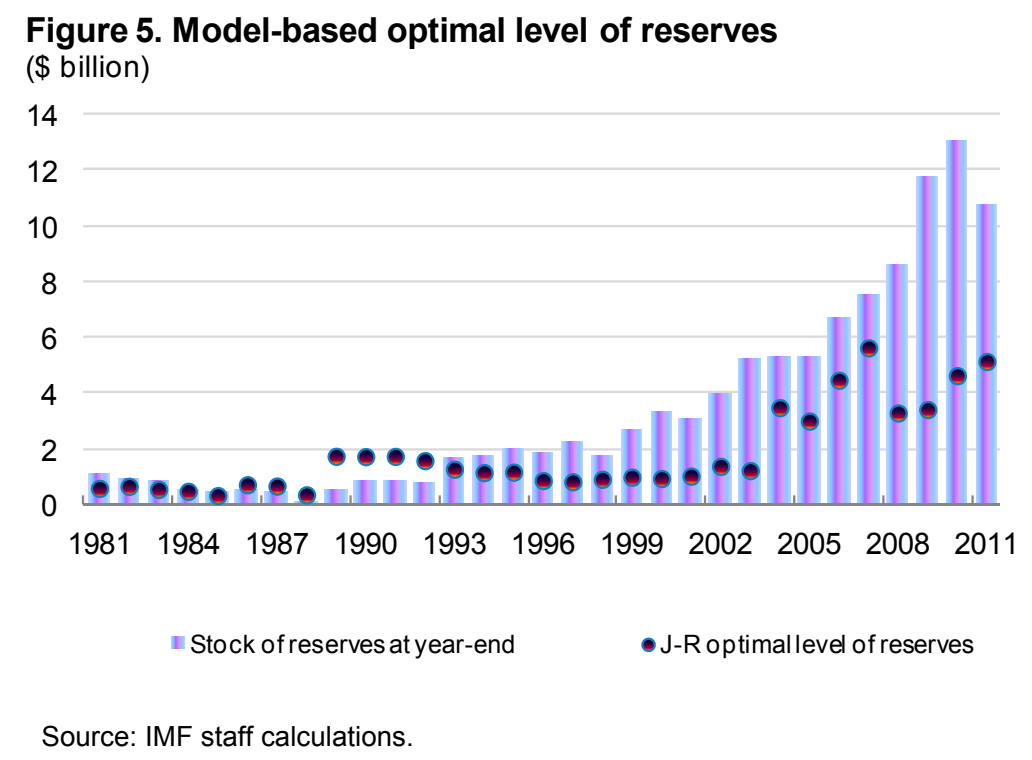

\section{The IMF's Risk-Weighted Metric}

5. This section uses a two-stage "risk-weighted" approach that encompasses a broad set of risks to assess the optimal level of reserves in Jordan. Cross-country experience shows that balance of payment pressures can arise from a range of different sources including external liabilities as well as current account variables and some measure of potential capital flight (these sources include export income, short term debt at remaining maturity, other portfolio liabilities, and liquid domestic assets). Therefore in the first stage, we employ a metric that reflects the relative risk levels of different potential sources of balance of payments pressure-the relative risk weights are based on tail event outflows associated with periods of exchange market pressure in different countries; and in the second stage we assess how much reserves might be needed relative to this risk weighted measure to cover the outflows from different sources. For Jordan (with a fixed exchange rate regime) the metric is constructed as follows:

$30 \%$ of short-term debt $+15 \%$ of other portfolio liabilities $+10 \%$ of $M 2+10 \%$ of imports.

Coverage in the region of 100-150 percent of the metric can be regarded as adequate for countries similar to Jordan.

6. Based on this approach and consistent with other methodologies, the level of reserves for Jordan is comfortably higher than suggested by the IMF's risk-weighted metric. Figure 6 shows Jordan's reserve coverage against the proposed adequacy range of 
100-150 percent (dashed lines). In the last decade, the actual level of reserves in Jordan has been well above this range.

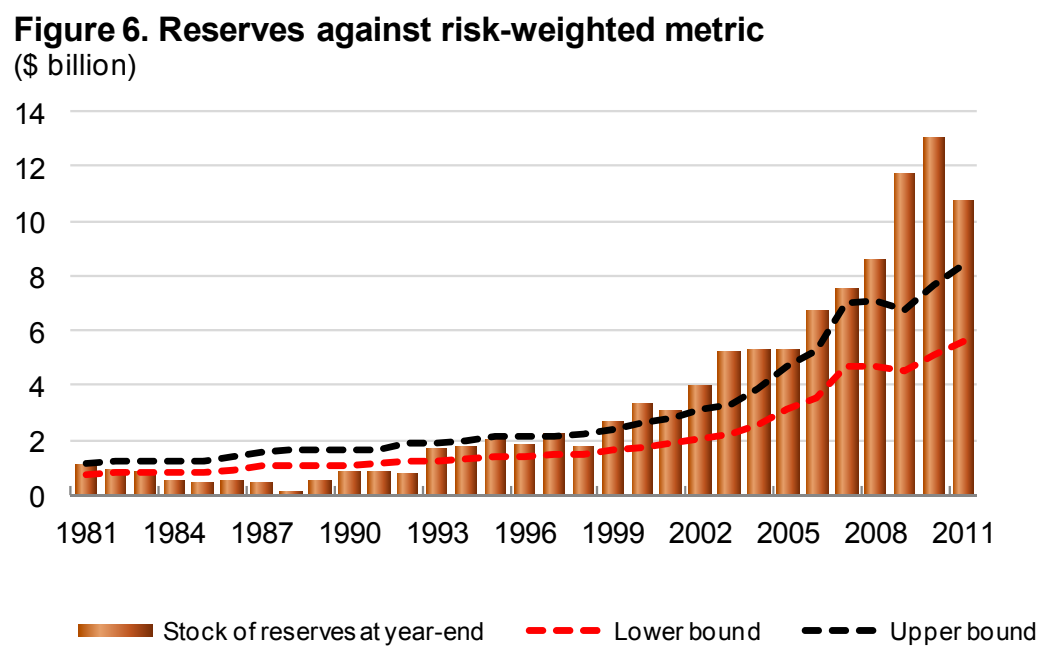

Source: IMF staff calculations.

\section{To conclude, according to these three approaches, Jordan's level of foreign} reserves is more than adequate to cover a broad set of conventional risks. However, no one measure is complete and can capture the full range of factors that bear on a country's resilience against shocks, and international reserves are only one part of a country's defense against such shocks. As a complement to these approaches, regression analysis of observed reserve holdings against a range of precautionary variables can be used to infer the degree to which Jordan's actual reserve levels are consistent with those of peers. Other factors to consider are central bank swap lines, sovereign wealth funds, and access to IMF credit lines, which can also provide contingent protection. A sound macroeconomic and prudential policy framework is probably more important than reserves in limiting country vulnerabilities. Low and sustainable levels of public debt, monetary and exchange policies that maintain both low inflation and a real exchange rate near equilibrium, and effective supervision that limits systemic risks from the banking sector, are all factors that will substantially reduce the probability of a crisis.

\section{Reference}

Jeanne, O., and R. Rancière, 2011, "The Optimal Level of International Reserves For Emerging Market Countries: A New Formula and Some Applications," The Economic Journal, Vol. 121, pp. 905-30. 


\section{JORDAN-FINANCIAL CONDITIONS INDEX ${ }^{1}$}

This chapter uses an analytical framework to construct a financial conditions index (FCI) for Jordan. Estimated FCI can be used as an additional tool to assess the monetary and financial policy stance, and to forecast real output movements. In the second half of 2011 financial conditions in Jordan remained relatively tight compared with long-term averages.

\section{The financial conditions index measures the contribution of domestic financial} conditions to real sector developments. It helps to summarize various dimensions of the financial sector, including exchange rate dynamics, monetary policy responses, developments in credit and asset prices, as well as the risk premium. The index is calculated using a country-specific model that links a number of financial indicators to GDP growth, while controlling for relevant domestic and external factors. ${ }^{2}$

2. The calculation involves three steps. First, a country-specific vector autoregressive model (VAR) is estimated using quarterly data. Then generalized impulse responses of Pesaran and Shin (1998) are calculated to assess the cumulative impact of the financial sector variables on GDP growth. Lastly, estimated elasticities are used as weights for the FCI, with all variables expressed as deviations from the sample mean.

\section{Following the global crisis in $\mathbf{2 0 0 8}$, financial conditions tightened markedly} relative to long-term averages, ${ }^{3}$ reflecting a sharp decline in stock prices, significant appreciation of the real exchange rate, and a widening spread to the U.S. policy rate. By the beginning of 2011 this negative contribution of domestic financial conditions to real sector developments had mostly unwound.

\section{In the second half of $\mathbf{2 0 1 1}$ domestic financial conditions in Jordan have again} tightened somewhat. The effect from a depreciating real exchange rate has been more than offset by the decline in stock prices that followed the regional unrest, and moderating real credit growth. The policy rate was tightened marginally in Q2 2011, but the spread to the U.S. policy rate remains low relative to its historical average.

\footnotetext{
${ }^{1}$ Prepared by Hirut Wolde and Anna Ter-Martirosyan.

${ }^{2}$ Calculations of the FCI closely follow the methodology discussed in the IMF's Asia and Pacific Department Spring 2009 Regional Economic Outlook (Box 1.4) and Guichchard and Turner (2008). There is also related work by Swiston (2008) that uses a similar approach.

${ }^{3}$ For Jordan, the main variables used to construct the FCI are: the policy interest rate (measured as a differential against the U.S. policy rate); real effective exchange rate (measured as a deviation from trend); credit growth (measured as a change in real credit defined as $\ln [$ credit/price index(CPI)]); and stock market prices (measured as a change in the stock price index deflated by the CPI).
} 
Figure 1. Jordan - Financial Conditions Index

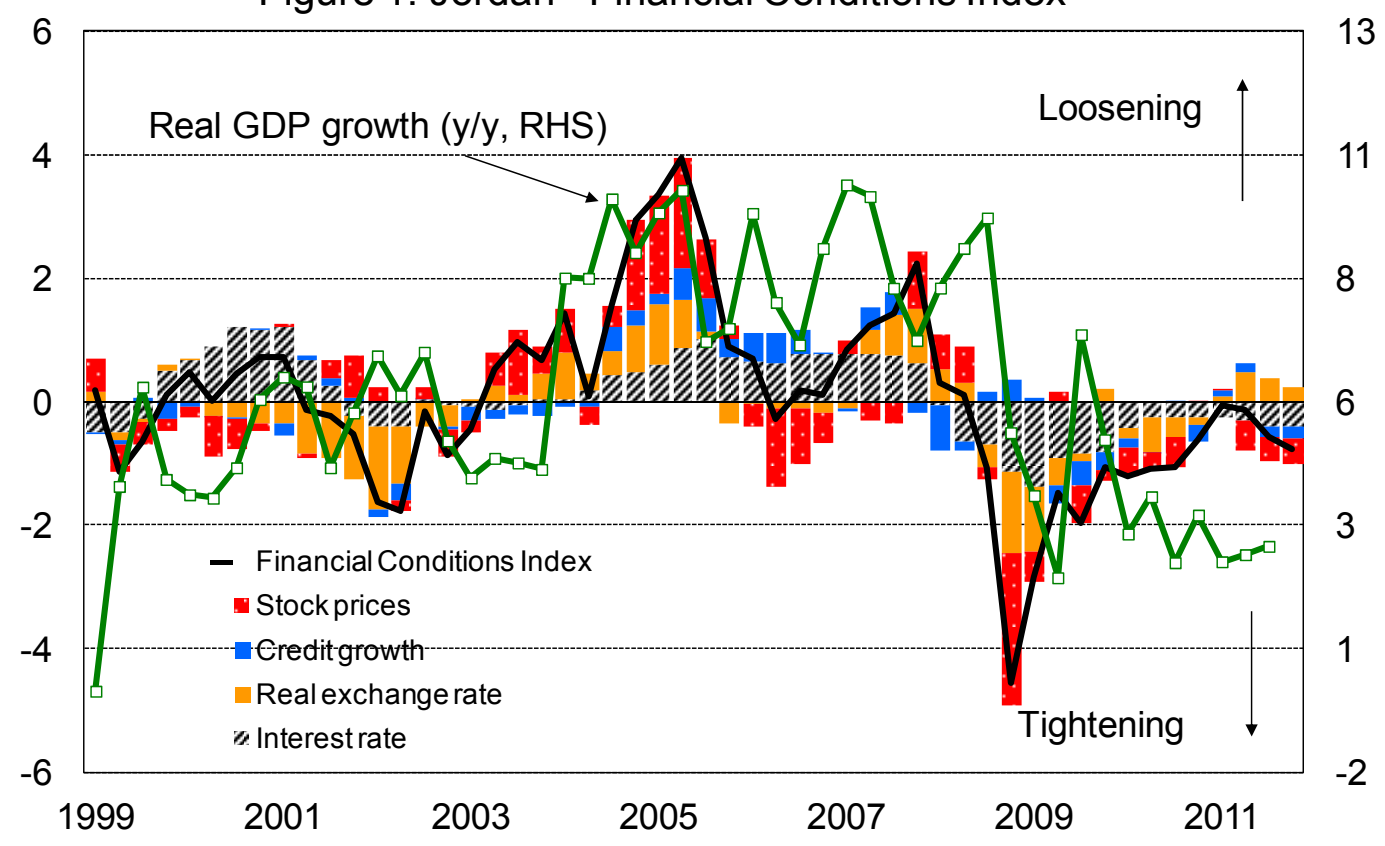

Source: IMF staff calculations.

\section{References}

Guichard, S., and D. Turner, 2008, "Quantifying the Effect of Financial Conditions on U.S. Activity," OECD Economics Department Working Papers, No. 635, OECD Publishing.

Guichard, S., D. Haugh, and D. Turner, 2009, "Quantifying the Effect of Financial Conditions in the Euro Area, Japan, United Kingdom and United States," OECD Economics Department Working Papers, No. 677, OECD Publishing.

Gauthier C., C. Graham, and Y. Liu, 2004, "Financial Conditions Indexes for Canada," Bank of Canada Working Paper 2004-22.

Pesaran, M.H., and Y. Shin, 1998, "Generalized Impulse Response Analysis in Linear Multivariate Models,” Economics Letters, Vol. 58, pp.17-29.

Swiston, A., 2008, “A U.S. Financial Conditions Index: Putting Credit Where Credit Is Due," IMF Working Paper 08/161 (Washington: International Monetary Fund). 


\section{DRIVERS OF GROWTH IN JORDAN ${ }^{1}$}

This chapter analyses the main drivers of growth in Jordan, and considers possible structural reforms to foster inclusive growth. Stylized facts on the relative size and contributions to real GDP growth of different sectors (over the last three decades) indicate the main engines of growth in Jordan. Structural reforms aimed at reducing the number of distortions and regulations in goods and labor markets will enhance job creation.

1. Jordan has experienced high growth rates during the last decade. The economy expanded at an average growth rate of about 6 percent between 2000-10. Real GDP growth doubled from 4 percent in 2000 to 8 percent in 2007, in line with strong global growth during that same period. After 2007 growth rates declined, and this economic slowdown was amplified by the global economic crisis. Growth rates are projected to recover in the medium term (Figure 1). While growth is necessary to reduce inequality and unemployment, it might not always be sufficient.

Figure 1. Real GDP growth rate in Jordan (in percent)

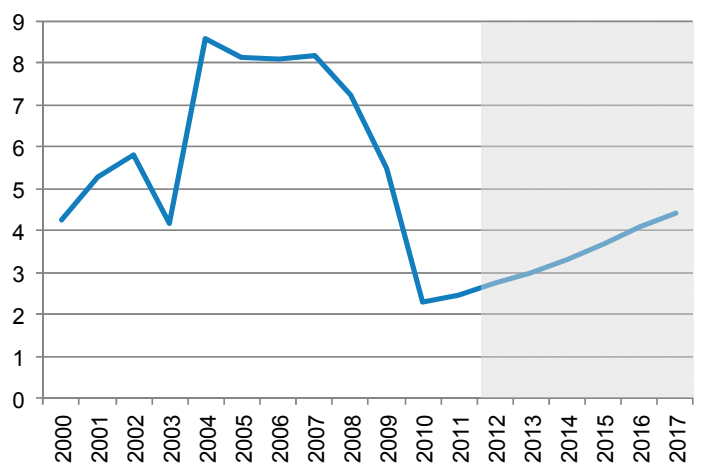

Sources: Jordanian authorities and IMF staff projections
Figure 2. Sector shares of GDP by decade (median, in percent)

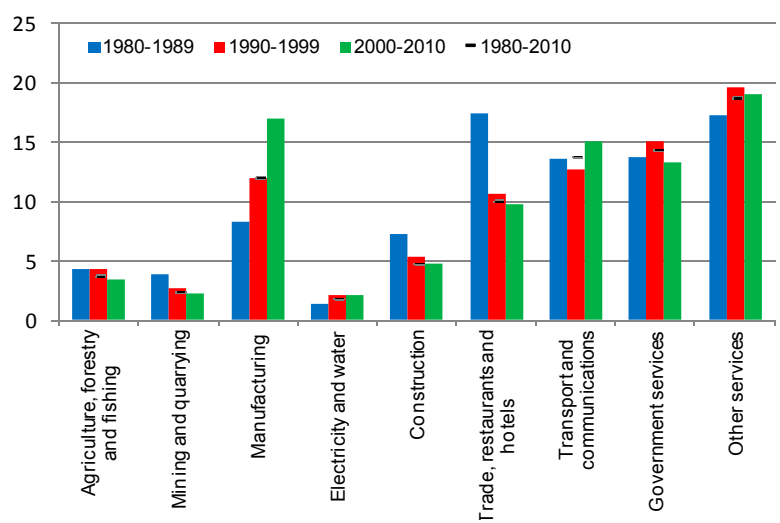

Sources: Jordanian authorities and IMF staff estimates.

2. An effective inclusive growth strategy should be centered around creating jobs, reducing inequality and providing equal opportunities so that all segments of the population can benefit from higher growth. In order to identify key sectors which can generate more employment, it is necessary to have an assessment of the main drivers of growth. In particular, which are the largest sectors in the economy? Which sectors contribute more to economic growth?

\footnotetext{
${ }^{1}$ Prepared by Agustin Roitman.
} 
3. During the last three decades, "Other services" (mainly finance and insurance services) have represented the largest sector in the Jordanian economy, followed by "Government services", "Transport and telecommunications" and "Manufacturing". The "Trade, restaurants and hotels" sector has become relatively small, since its share of GDP decreased from an average of 17 percent between 1980 and 1989 to less than 10 percent between 2000 and 2010. Concurrently, the "Manufacturing" sector expanded significantly, doubling in size between 1980 and 2010 (Figure 2).

4. In general, the larger sectors are, and have historically been, the most important engines of growth in Jordan. "Manufacturing" and "Other services" have both been the greatest contributors to growth. The latter, being particularly important during 1990 to 1999 , and the former, during 2000 to 2010. For the year 2010, "Other services" was the main driver of growth, comprising finance and insurance services as well as real estate (Table 1).

Table 1. Sectoral contribution to real growth in percentage points (median)

\begin{tabular}{lccccc}
\hline & & & & & \\
& $1980-2010$ & $1980-1989$ & $1990-1999$ & $2000-2010$ & 2010 \\
\hline Agriculture, forestry and fishing & 0.16 & 0.07 & 0.11 & 0.29 & 0.26 \\
Mining and quarrying & 0.08 & 0.19 & 0.04 & 0.14 & 0.30 \\
Manufacturing & 0.90 & 0.24 & 0.68 & 1.21 & 0.34 \\
Electricity and water & 0.12 & 0.12 & 0.14 & 0.10 & -0.05 \\
Construction & 0.23 & -0.24 & 0.10 & 0.42 & -0.30 \\
Trade, restaurants and hotels & 0.37 & -0.30 & 0.24 & 0.54 & -0.17 \\
Transport and communications & 0.50 & 0.48 & 0.47 & 0.74 & 0.74 \\
Government services & 0.47 & 0.84 & 0.46 & 0.45 & 0.45 \\
Other services & 0.88 & 0.53 & 0.93 & 1.13 & 1.43 \\
\hline
\end{tabular}

Sources: Jordanian authorites and IMF staff estimates.

\section{A. Structural Reforms to Create Jobs and a More Inclusive Growth Path}

5. A stable macroeconomic environment is crucial to foster a vibrant and dynamic business environment. This, in turn, would provide incentives to invest, create new firms, expand existing firms, attract FDI and create jobs. As of 2011, the Jordanian economy is below average in several categories of world rankings of the Doing Business Report 2011 (Table 2). ${ }^{2}$

\footnotetext{
${ }^{2}$ This is a co-publication of The World Bank and the International Finance Corporation, and includes 183 economies.
} 


\begin{tabular}{|c|c|}
\hline Ease of Doing Business Rank & 96 \\
\hline Starting a Business & 95 \\
\hline Dealing with Construction Permits & 93 \\
\hline Getting Electricity & 36 \\
\hline Registering Property & 101 \\
\hline Getting Credit & 150 \\
\hline Protecting Investors & 122 \\
\hline Paying Taxes & 21 \\
\hline Trading Across Borders & 58 \\
\hline Enforcing Contracts & 130 \\
\hline Resolving Insolvency & 104 \\
\hline
\end{tabular}

Source: Doing Business Report 2011. The World Bank and the International Finance Corporation.

6. Government policies to achieve more inclusive growth should remove economic distortions and guarantee equal opportunities to start a business, access credit, and purchase land and other factors of production. Fewer economic distortions will reduce rent-seeking activities and therefore contribute to create a better business environment where returns from growth are received by all segments of the population, not just a privileged few.

7. Starting a business and especially getting credit in Jordan is more difficult than in the average country in the world. Moreover, compared to global best practice and relevant selected economies, Jordan is lagging behind (Figures 3 and 4).

Figure 3. Starting a Business - Global Rank

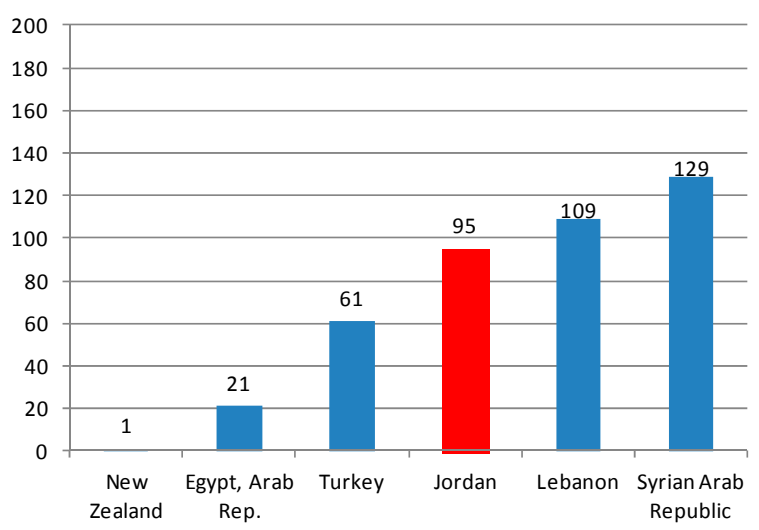

Source: Doing Business Report 2011. The World Bank and the International Finance Corporation.
Figure 4. Getting Credit - Global Rank

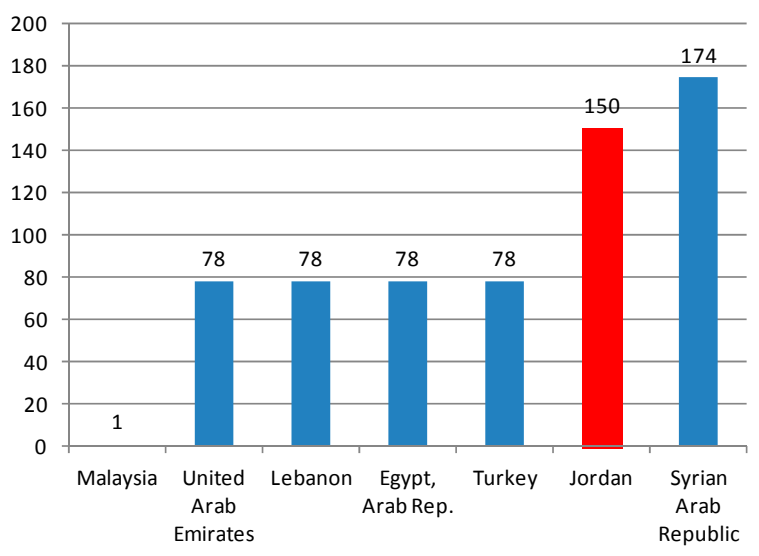

Source: Doing Business Report 2011. The World Bank and the International Finance Corporation. 
8. Jordan could enhance job creation through a better business environment, by reducing the number of procedures, as well as the cost and the time required of each procedure to start a business. The strength of legal rights to protect borrowers and lenders through collateral laws, and the scope and accessibility of credit information (both private and public) could be further improved, since they are actually below the global average and below relevant comparator countries.

9. All in all, better rules and regulations aimed at reducing the cost of starting a business (especially SMEs) would not only increase investment and growth, but would also create a more vibrant and dynamic private sector which would in turn create jobs. Given that the manufacturing sector has grown strongly in the last 30 years and the services sector remains relatively large, special emphasis on improving the business environment in these sectors (as opposed to the mining sector which tends to be more capital intensive), would enhance their flexibility and therefore their potential to create jobs and contribute to placing the Jordanian economy on a more inclusive and sustainable growth path. 


\section{Fiscal and Debt Implications of Mega Projects ${ }^{1}$}

Jordan is considering a significant expansion of its public-private partnerships through three large projects: a railway, a project to desalinate water from the Red Sea, and a nuclear power plant. The estimated cost of these "megaprojects" is about US\$15 billion (55 percent of 2010 GDP), which would be spread over many years. This chapter examines the fiscal and debt implications of mega projects, drawing on the findings of staff analysis.

\section{Jordan is contemplating a large expansion of its program of public-private} partnerships (PPPs) to finance three megaprojects: a railway, a project to desalinate water from the Red Sea, and a nuclear power plant.

- The railway project aims to improve Jordan's transport network. It would create modern rail links from Syria in the north to Aqaba in the south, and to the Iraqi and Saudi Arabian borders (at an estimated cost of about US $\$ 3.5$ billion, or 13 percent of 2010 GDP).

- The Red Sea project seeks to alleviate Jordan's extreme water shortages. Under the plan, a pipeline would be built between the Red Sea and the Dead Sea, and the sea water would be desalinated to supply fresh water to Amman, Aqaba, and other cities. The residual brine would be fed into the Dead Sea to halt the decline in water levels, and the 400 meter drop in the sea level on its way to the Dead Sea would be used to generate hydro electricity to provide some of the energy needed for desalination. The first phase of the project would provide 210 million cubic meters of potable water a year and is estimated to cost US\$5 billion (18 percent of 2010 GDP). Four further phases would ultimately increase capacity to 900 million cubic meters of water a year.

- The nuclear power plant would reduce the country's heavy dependence on imported fossil fuels, and could help prevent costly blackouts and brownouts. It may also reduce the long-term costs of energy. Capital costs for the construction of the plant are estimated at US\$5 billion (18 percent of 2010 GDP). However the project will necessitate off-site investments that will be borne directly by the government or the publicly-owned wholesale utility. These investments are estimated at US\$1.4 billion (5 percent of 2010 GDP), and include upgrading the power grid and building roads around the project site.

2. These projects are expected to have large positive externalities. Individual railway lines could be built for less, but each line would bring traffic to all the others (there are positive network externalities) so the whole may be more valuable than the sum of the parts.

\footnotetext{
${ }^{1}$ Prepared by Nkunde Mwase.
} 
Tourist resorts and real-estate developments on the route of the Red Sea pipeline are envisaged.

\section{The fiscal and debt implications of the megaprojects are crucial in deciding} whether to go forward with them. The megaprojects will create direct and guaranteed debt, which both count as public debt under the Jordanian Debt Law. The projects also involve government-guaranteed long-term spending commitments by state-owned entities, which will reduce fiscal space in the future in much the same way that debt does.

\section{If implemented as planned, the megaprojects would place an enormous burden} on public finances (Table 1). IMF staff have estimated that they would increase the budget deficit by $1 \frac{1}{2}$ percentage points of GDP in 2012 and by 2 percentage points of GDP in 2020 . Higher deficits will add to direct debt, and public debt would increase by $4 \frac{1}{2}$ percentage points of GDP in 2012 and by more than 20 percentage points of GDP by 2020 . The Jordanian Government will also assume significant indirect obligations through guarantees of long-term contracts required by the private sector. Although these obligations are not included in the government's definition of debt, their economic effects are similar.

Table 1. Jordan: Consolidated Impact of Megaprojects on Central Government (Percent of GDP)

\begin{tabular}{|c|c|c|c|c|c|c|}
\hline & 2012 & 2013 & 2014 & 2020 & 2030 & 2050 \\
\hline Overall balance & -1.7 & -1.9 & -2.7 & -1.8 & -1.2 & -0.5 \\
\hline Revenues (dividends) & 0.0 & 0.0 & 0.0 & 0.2 & 0.4 & 0.3 \\
\hline Expenditures & 1.7 & 1.9 & 2.7 & 2.0 & 1.5 & 0.8 \\
\hline Subsidies $1 /$ & 0.0 & 0.0 & 0.0 & 1.2 & 0.4 & -0.1 \\
\hline Interest & 0.0 & 0.0 & 0.1 & 0.8 & 1.1 & 0.9 \\
\hline Capital spending and net lending 2 / & 1.7 & 1.9 & 2.6 & 0.0 & 0.0 & 0.0 \\
\hline Direct and indirect obligations & 5.2 & 11.2 & 16.9 & 32.3 & 21.1 & 13.2 \\
\hline Public debt (Government definition for debt law) & 4.3 & 9.3 & 13.7 & 20.5 & 16.1 & 12.1 \\
\hline Railway & 2.6 & 5.0 & 7.1 & 7.3 & 4.6 & 0.8 \\
\hline Red-Dead & 0.0 & 1.2 & 2.2 & 6.6 & 9.5 & 11.2 \\
\hline Nuclear & 1.7 & 3.2 & 4.4 & 6.5 & 1.9 & 0.1 \\
\hline Direct debt (all projects) & 1.7 & 3.6 & 5.2 & 11.0 & 14.6 & 12.0 \\
\hline Guaranteed debt (all projects) & 2.6 & 5.7 & 8.6 & 9.5 & 1.4 & 0.1 \\
\hline Other PPP guarantees (e.g. guarantee of WPA or PPA) & 0.9 & 1.9 & 3.1 & 11.8 & 5.1 & 1.0 \\
\hline
\end{tabular}

Source: IMF staff estimates.

Note: WPA is water-purchase agreement and PPA is power-purchase agreement.

$1 /$ Losses on sales that result in higher deficit in public companies.

2/ To cover government equity participation and off-site investments. 
5. The megaprojects will provide significant revenue to the Jordanian Government, but the stream of revenue associated with them is back-loaded. Given the long construction period for these projects, no significant revenue will accrue to the government before 2020. From 2020 onward, however, these nontax revenues will increase from 0.2 percent of GDP to over 0.3 percent of GDP after 2030. Public debt and other obligations will begin to fall after 2018 .

6. Even under a more optimistic economic growth assumption, the negative fiscal impact of the project would still be sizable. If the real growth rate was 4 percent per year from 2016 onward, public debt ratios would be lower than in the baseline by only $1 / 2$ of a percentage point of GDP in 2020 and 2 percentage points of GDP in 2030.

7. Improving the process of public investment planning, implementation, and evaluation is crucial in deciding whether the megaprojects, or other public investment programs, provide the best use of Jordan's fiscal resources. A strong framework in this area is needed regardless of whether projects are executed through traditional public procurement or PPPs. 


\section{The EMPloyment Challenge FACING JoRdan ${ }^{1}$}

Addressing high unemployment, particularly among the young, is a longstanding challenge for Jordan. To boost job creation and enhance the employability of young people, policymakers can in the short term bring forward labor-intensive infrastructure investments, provide tax incentives or credit guarantees to viable labor-intensive small-and medium-sized enterprises, and scale up promising training programs, or introduce new well-designed and effective ones. To have a lasting effect, however, such measures have to be combined with a comprehensive job strategy that fosters inclusive growth and transforms education systems.

1. Unemployment in Jordan is high, particularly among the young. In 2010, unemployment in Jordan registered 12.5 percent, higher than the average in the Middle East and North Africa (MENA) region of about 10 percent, which, in turn, was the highest regional rate worldwide (Figure 1). Unemployment in Jordan is largely a youth phenomenon. Young people, ages 15 to 24 , account for about 50 percent of the unemployed, and at 28 percent, the youth unemployment rate is among the highest in the world. In contrast to most of the world, unemployment rates in Jordan tend to be highest among the educated, exceeding 15 percent among those with college degrees.

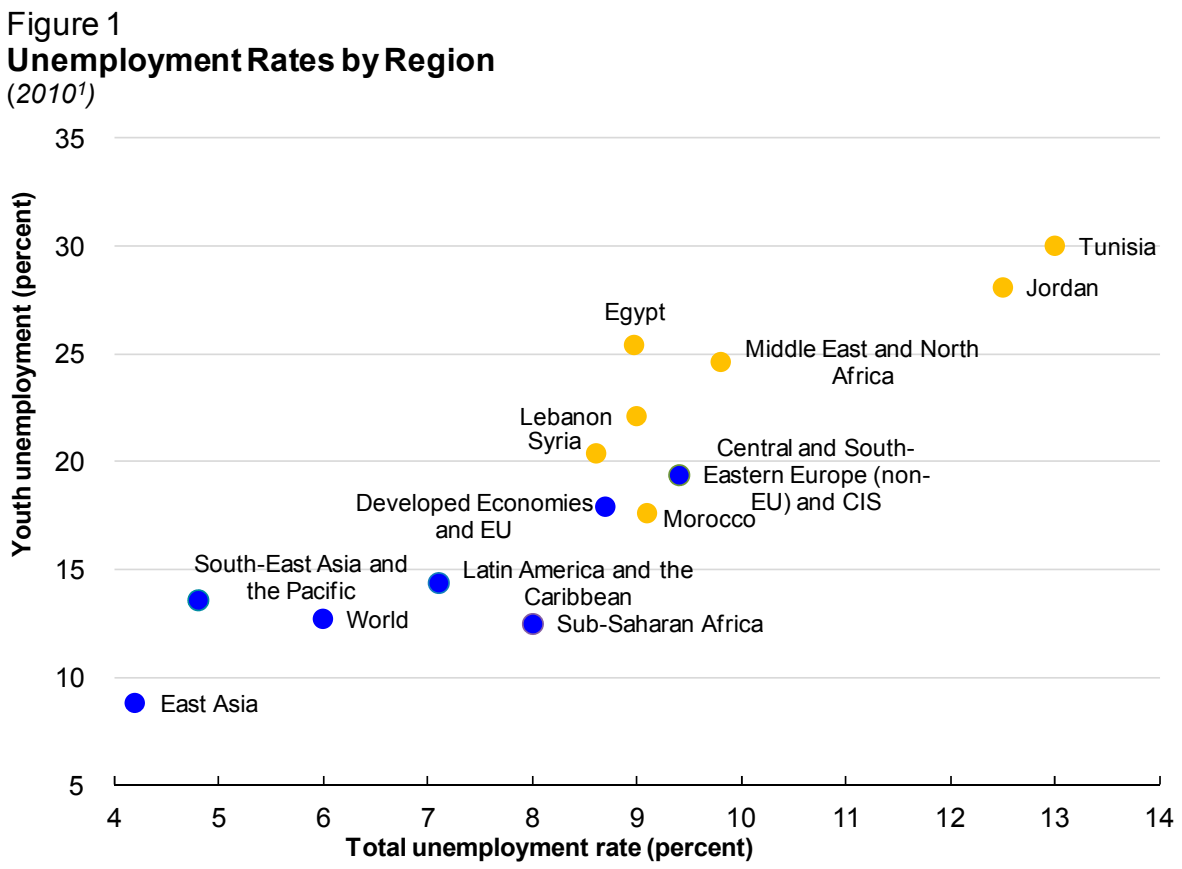

Sources: International Labor Organization, Global Employment Trends (2011), Global Employment Trends for Youth (2011); national authorities; and IMF staff estimates.

12007 data for Lebanon, 2008 youth unemployment rate for Egypt.

\footnotetext{
${ }^{1}$ Prepared by Yasser Abdih.
} 


\section{High unemployment in Jordan, together with a low labor force participation} rate, has resulted in a very low ratio of employment to working-age population. At about 40 percent, the labor force participation rate in Jordan is low when compared to elsewhere. With about 35 percent of working-age people actually employed, this rate is also among the lowest worldwide (Figure 2).

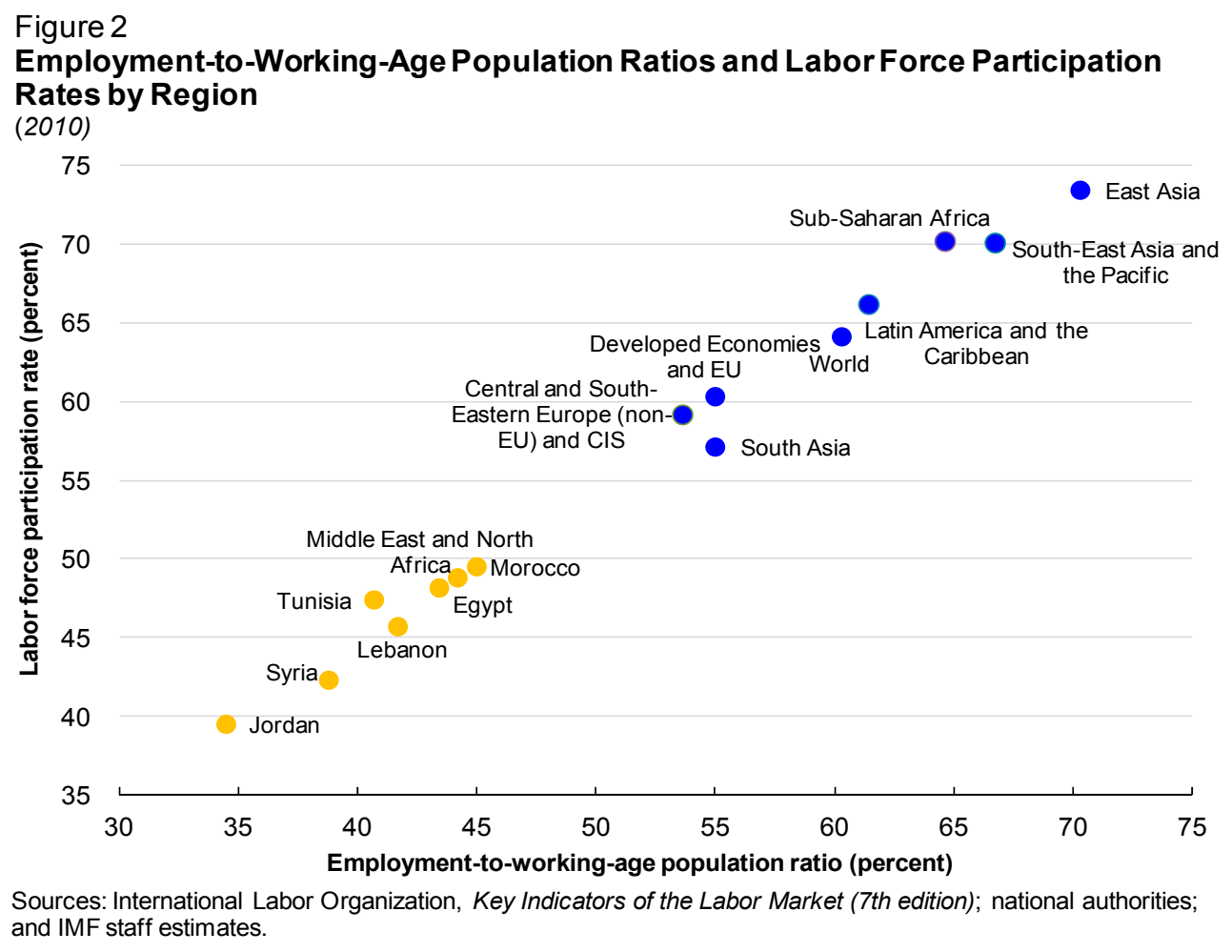

3. Looking ahead, Jordan faces a daunting employment challenge. To absorb the unemployed and new entrants to the labor force, Jordan will need to increase employment by an estimated 0.8 million full-time positions over the period 2010-20 (Table 1)—although even this would leave the employment to working-age population ratio in 2020 at 43 percent, lower than the average ratio currently observed in any region in the world (Figure 2). However, if the elasticity of employment with respect to output were to stay constant and the pace of output growth unchanged from the last decade, only 0.5 million new jobs would be created. Even this is optimistic given that current projections over the period 2010-17 point to an average annual GDP growth rate of 3.3 percent, about 2.9 percentage points lower than that achieved over the last decade. In fact, if the 3.3 percent average annual GDP growth were to materialize for the current decade (2010-20), then a mere 0.2 million new jobs would be created. Similarly, under the assumption of constant employment elasticity, creating 0.8 million new jobs would require annual real GDP growth of 9.3 percent3.2 percentage points higher than that achieved by Jordan during the period 2000-2010, and 6 percentage points higher than current projections over the period 2010-17 point to-a tall order (Table 1). 
Table 1. Growth Required to Absorb New Labor Force Entrants and Currently Unemployed

\begin{tabular}{lr}
\hline & Jordan \\
\hline 2010 & \\
\hline Labor force (millions) & 1.6 \\
Unemployment rate (percent) & 12.5 \\
$\quad$ Unemployed (millions) & 0.2 \\
Employed (millions) & 1.4 \\
2020 & \\
\hline Labor force (millions) & 2.2 \\
$2010-2020$ & \\
\hline New entrants to the labor force (millions) & 0.6 \\
Total number of currently unemployed and new entrants (millions) & $\mathbf{0 . 8}$ \\
Change in employment required to achieve target (percent) & 58.1 \\
Annual employment growth required to achieve target (percent) & 4.7 \\
\hline Employment elasticity (estimated) & \\
Required annual real GDP growth rate (percent) & 0.5 \\
Real GDP growth rate, 2000-2010 (percent) & 9.3 \\
Real GDP growth rate projections, 2010-2017 (percent) & 6.1 \\
\hline
\end{tabular}

${ }^{1}$ Using historical data since the early 1990 s, we estimate the elasticity of employment with respect to output starting with an Vector Autoregression (VAR) model involving the logarithms of employment and real GDP, and their lags. Using Johansen's test, the VAR system is found to be cointegrated. The cointegration relationship suggests an estimate of the employment elasticity of about 0.5 . The estimated employment elasticity is highly significant and stable over time.

4. Jordan can implement a number of immediate measures to step up job creation and enhance the employability of its young population. One opportunity, for example, is to bring forward viable labor-intensive smaller-scale infrastructure projects that are already in the pipeline. This strategy would not just provide employment for workers in the short term, but would also enhance Jordan's long term growth through the benefits of improved infrastructure. Policymakers can also provide tax incentives or credit guarantees to viable labor-intensive small- and medium-sized enterprises, as implemented in many emerging markets and transition economies during the global financial crisis. Another option is to introduce well-designed youth-oriented training programs, or to scale up and replicate promising existing ones, such as the Education for Employment Foundation, which works with corporations and industries to assess demand for skills and to provide corresponding tailored training programs for young people. (For a discussion of these issues, see IMF, April 2011, Regional Economic Outlook: Middle East and Central Asia). 
5. To have a lasting effect, however, short-term measures have to be combined with a comprehensive job strategy that fosters inclusive growth and transforms education systems. High economic growth remains a key pillar of generating jobs for new labor market entrants. For growth to have the maximum impact on job creation, it also needs to be inclusive, benefiting all segments of the population — not just a privileged few. Sustained growth will need to be driven by the private sector. The government can create an enabling environment, including by providing a level playing field and a healthy business climate. To enhance skill formation, primary, secondary, and tertiary curricula need to be better aligned with the needs of the private sector. In this context, reforming university admissions policies to test a broad range of skills - writing, critical thinking, and problem solving — would give incentives for students at the primary and secondary levels to acquire such skills. (For more details, see IMF, April 2011, Regional Economic Outlook: Middle East and Central Asia). 


\section{Taking Stock of Public Investment Efficiency, Capital Accumulation AND Total FaCtor Productivity in JORDAN ${ }^{1}$}

Given Jordan's low levels of capital per worker and relatively efficient investment process, capital spending could have high returns. However, for increased capital spending to have a maximum impact on productive capital accumulation and output, further reforms are needed to enhance the process of evaluation of investment projects.

1. A scaling-up of public investment is central to growth. Growth rates in Jordan averaged 6 percent in the last decade on the back of strong FDI, remittances and tourism receipts. Going forward the economy will struggle in the face of limited government spending and any slowing of inflows from the Gulf-growth is likely to remain well below the average level observed in the 2000-10 period. Although the overall quality of infrastructure is decent (Figure 1), an effective strategy to boost output could consider improvements in infrastructure, particularly railroads. Arguments for boosting investment in physical infrastructure to achieve growth rest on high returns to investment in capital-scarce environments, and the deficiencies in these areas.

Figure 1. Jordan Infrastructure:

Percentile Rankings of Sub-Indicators, 2011

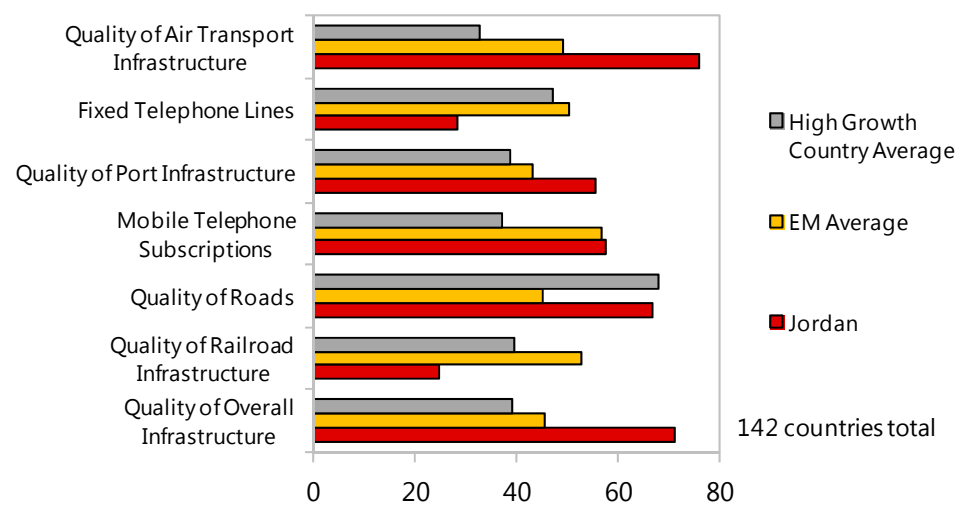

Source: World Economic Forum's Global Competitiveness Index.

2. Public investment spending is not always efficient. Inefficiency, waste, or corruption often distorts the impact of public spending on capital accumulation, resulting in inadequate returns to public and private investment in many countries (Pritchett, 2000). Low returns arise from poor selection and implementation of projects, waste and leakage of resources, and weak technical expertise. Accounting for public investment inefficiencies will have consequences not only for estimating returns to public sector capital, but also for decomposing output into factor accumulation and total factor productivity (TFP). Unfortunately, development accounting exercises unadjusted for public investment inefficiencies can overstate physical capital available for production and understate TFP.

\footnotetext{
${ }^{1}$ Prepared by Annette Kyobe.
} 
3. In this chapter, we take stock of public investment management and capital stock accumulation in Jordan and calculate capital's contribution to output per worker. Decomposing output into factor accumulation, using capital and capital adjusted for investment inefficiencies, it follows that more efficient investment spending translates into higher capital accumulation with which to increase output.

\section{A. Efficient Public Investment}

4. The public investment management process is relatively efficient in Jordan. A composite public investment management index (PIMI), which serves as a proxy for investment efficiency, scores Jordan in the fourth quartile in a sample of 71 emerging and developing countries, behind Tunisia (in the top 5) and ahead of Yemen and West Bank and Gaza which are near the bottom (Figure 1). ${ }^{2}$ The region as a whole performs quite poorly (the worst except for Sub-Saharan Africa) displaying weaknesses in all stages of the investment process.

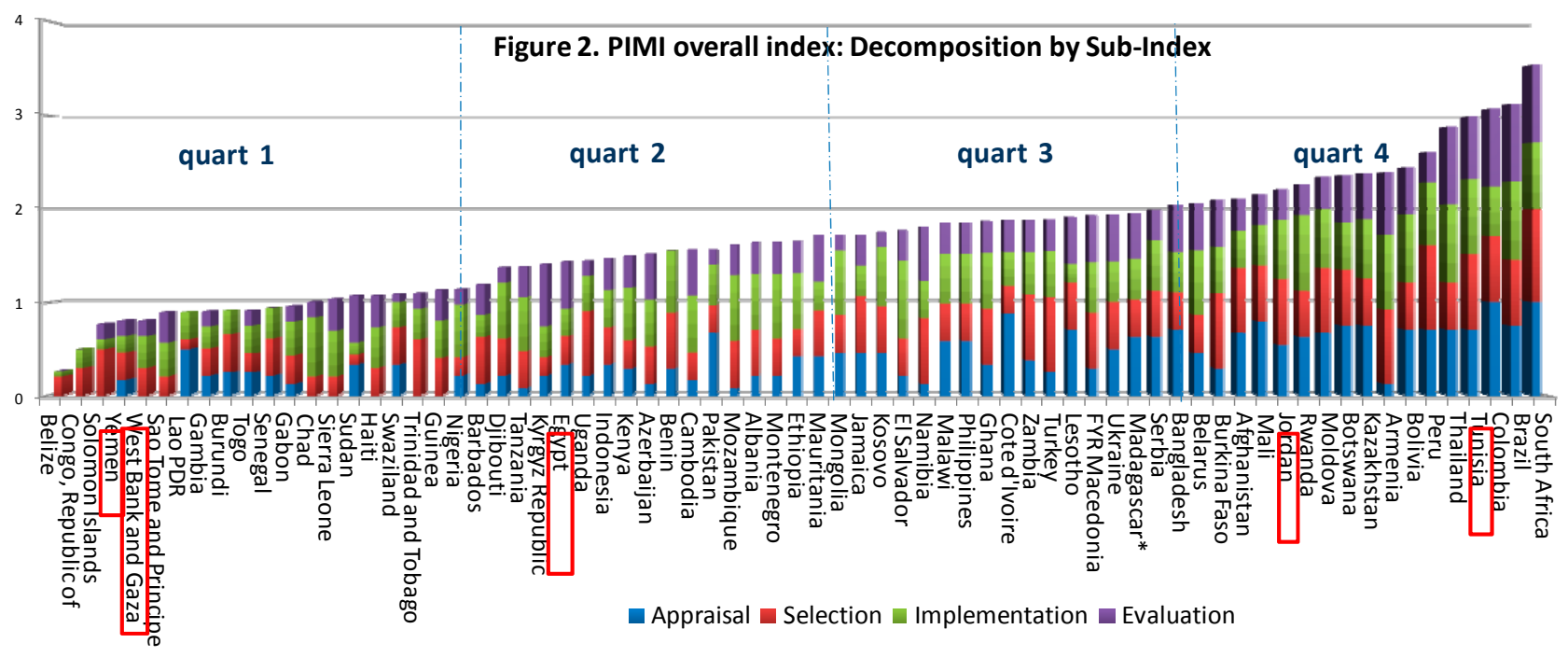

\footnotetext{
${ }^{2}$ See Dabla-Norris et al. (2010). The index measures the efficiency of investment by evaluating the investment process across four consecutive stages: strategic guidance and project appraisal; project selection; project management and implementation; and project evaluation and audit. The sample includes five Middle East and North African (MENA) countries-Egypt, Jordan, Tunisia, Yemen and the West Bank and Gaza.
} 


\section{Jordan performs well in all but the last stage of the investment process.}

Evaluation is weak as projects are not assessed frequently; only some central government expenditures are audited and although there is registry of public sector assets, it is incomplete. ${ }^{3}$ This example points to the vastly different performance across the four stages of the investment process among countries, and highlights the country-specific policy actions that can be taken to improve investment efficiency (Figure 3).

Figure 3. PIMI Index and its Subcomponents: Select Countries in MENA

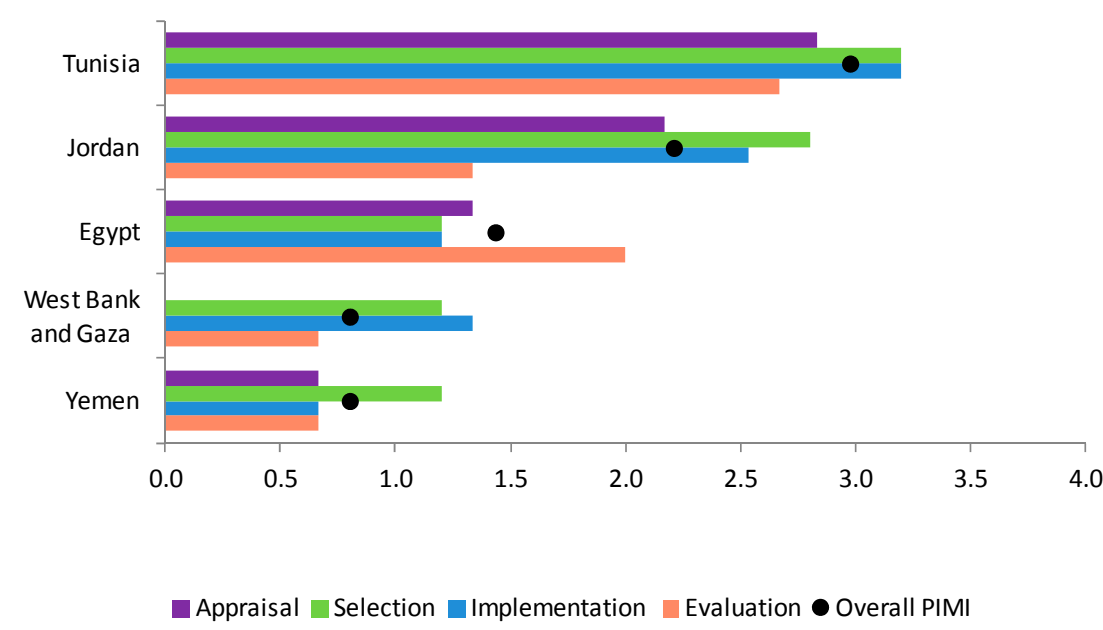

\section{B. Decomposing Output per Worker}

\section{A development accounting exercise is conducted to quantify the contribution of} capital accumulation and TFP to output. The focus is on levels rather than growth rates, following a number of contributions to the literature, for example Barro and Sala-i-Martin (2004), who determine it is the long run differences in levels (the economic performance most relevant to welfare and the consumption of goods and services) that are most interesting to explain. Two estimates of TFP are developed: one using standard capital stocks constructed by the perpetual inventory method, and the second using PIMI-adjusted capital stocks accounting for public investment efficiency (taken from Gupta et al. 2011). ${ }^{4}$ TFP is derived from the Cobb-Douglas production function and is calculated by subtracting from output per worker the product of human capital share $\left(\alpha_{h}=0.3\right)$ and human capital, and the

\footnotetext{
${ }^{3}$ According to recent findings by IMF staff, the General Budget Department does not conduct regular ex-post evaluation of investment projects.

${ }^{4}$ Following Pritchett (2000), the paper constructs an adjusted public capital stock series. Capital stock is calculated using the perpetual inventory method $K_{i t}^{p}=K_{i t-1}^{p}-\partial_{i t} * K_{i t-1}^{p}+p_{i}^{*} I_{i t-1}$, where $K_{i t}^{p}$ is the stock of public capital at time t, $I_{i t-1}$ is public investment spending at time $\mathrm{t}-1, \partial_{i t}$ is the rate of depreciation of capital stock and $p_{i}$ is the PIMI index, normalized from 0 to 1 which captures investment efficiency. Resulting public capital is added to private capital to yield total capital stocks.
} 
product of physical capital share $\left(\alpha_{k}=0.4\right)$ and physical capital. Shares are standard in the literature and human capital is derived converting "years of schooling" to human capital accumulation, following Hall and Jones (1999):

$$
\ln T F P_{i t}=\ln y_{i t}-\alpha_{h} \ln h_{i t}-\alpha_{k} \ln k_{i t} .
$$

Table 1 decomposes results into the contributions from factor inputs, human and physical capital and TFP.

7. Output per worker varies considerably within the MENA region. Countries with the highest output per worker-Saudi Arabia, Iran and Egypt — are those with the highest productivity and highest capital stock (Figure 4). ${ }^{5}$ Jordan, Yemen and Syria have the lowest output per worker, with Jordan producing less than most countries in the region except for Bahrain and Yemen. Looking across regions, average annual output per worker is lower in MENA than most regions, with the exception of Latin America and the Caribbean and SubSaharan Africa (Table 1).

Figure 4. Output per Worker: MENA Region
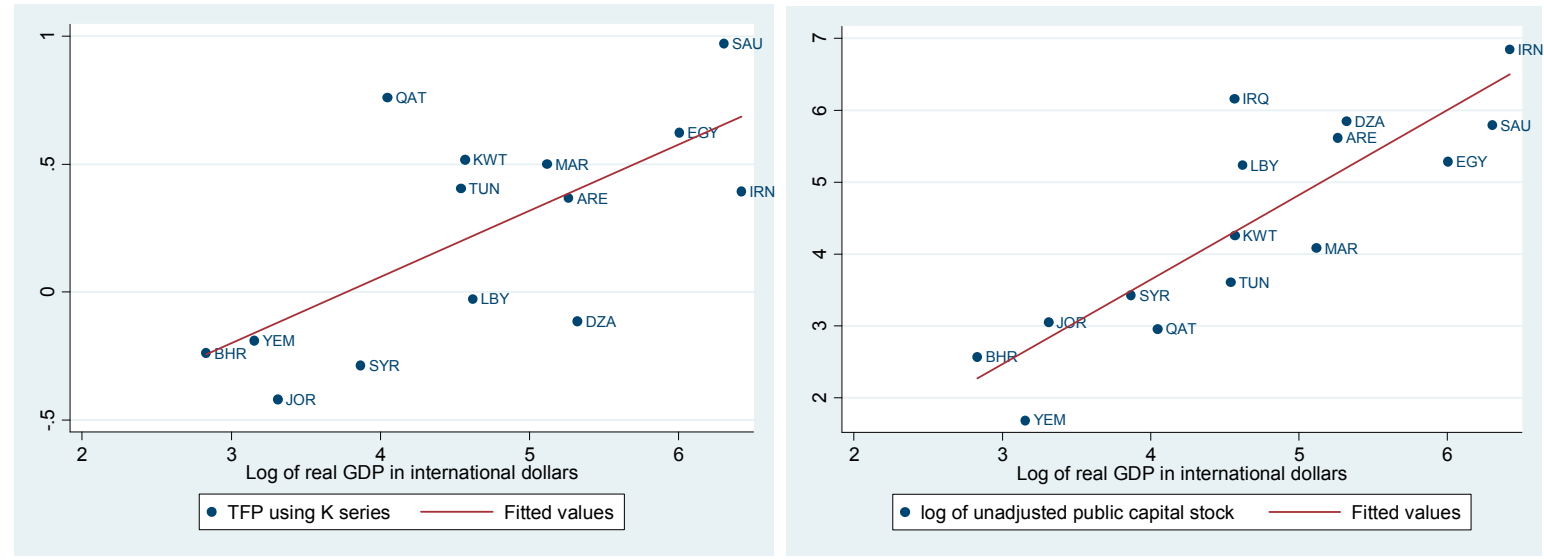

Source: IMF staff calculations.

\footnotetext{
${ }^{5}$ The contribution of oil and gas is subtracted in calculating output for oil exporters.
} 
Table 1. Decomposition of Output Per Worker, Average, 1992-2008

\begin{tabular}{|c|c|c|c|c|c|c|c|}
\hline & \multirow[b]{3}{*}{$\begin{array}{c}\text { Output/ } \\
\text { worker }\end{array}$} & \multicolumn{5}{|c|}{ Contribution of } & \multirow{3}{*}{$\begin{array}{r}\text { Public } \\
\text { Investment } \\
\text { Ratio }\end{array}$} \\
\hline & & \multicolumn{3}{|c|}{ Capital/Worker } & & & \\
\hline & & Physical & $\begin{array}{l}\text { Physical } \\
\text { (PIM) 1/ }\end{array}$ & Human & TFP & $\begin{array}{r}\text { TFP } \\
\text { (PIM) 1/ }\end{array}$ & \\
\hline Non-oil & 4.3 & 1.4 & 1.3 & 2.7 & 0.3 & 0.4 & 2.5 \\
\hline Egypt & 5.8 & 2.1 & 1.7 & 3.2 & 0.5 & 0.9 & 2.5 \\
\hline Jordan & 3.1 & 1.2 & 0.9 & 2.4 & -0.5 & -0.3 & 4.2 \\
\hline Morocco & 4.9 & 1.6 & $\ldots$ & 2.9 & 0.4 & $\ldots$ & 2.0 \\
\hline Syria & 3.7 & 1.3 & $\ldots$ & 2.7 & -0.4 & $\ldots$ & 4.5 \\
\hline Tunisia & 4.3 & 1.4 & 1.3 & 2.6 & 0.3 & 0.4 & 2.3 \\
\hline Oil 2/ & 4.0 & 2.1 & 0.0 & $2.6^{r}$ & -0.3 & 0.3 & 5.2 \\
\hline Bahrain & 2.4 & 1.0 & $\ldots$ & 2.0 & -0.6 & $\ldots$ & 3.6 \\
\hline Algeria & 4.9 & 2.3 & $\ldots$ & 3.0 & -0.4 & $\ldots$ & 11.8 \\
\hline Iran & 6.2 & 2.7 & $\ldots$ & 3.2 & 0.3 & $\ldots$ & 8.6 \\
\hline Iraq & 4.5 & 2.4 & $\ldots$ & 2.8 & -0.6 & $\ldots$ & 20.0 \\
\hline Kuwait & 4.0 & 1.7 & $\ldots$ & 2.3 & 0.0 & $\ldots$ & 2.9 \\
\hline Libya & 3.3 & 2.1 & $\ldots$ & 2.5 & -1.3 & $\ldots$ & 9.5 \\
\hline Qatar & 3.2 & 1.1 & $\ldots$ & 2.0 & 0.1 & $\ldots$ & 5.2 \\
\hline Saudi Arabia & 6.0 & 2.3 & $\ldots$ & 2.9 & 0.7 & $\ldots$ & 3.3 \\
\hline Yemen & 2.8 & 0.5 & 0.0 & 2.6 & -0.3 & 0.3 & 1.9 \\
\hline Standard deviation (across MENA) & 1.2 & 0.6 & 0.8 & 0.4 & 0.5 & 0.4 & 4.9 \\
\hline Advanced Economies & 5.9 & 2.4 & 2.4 & 3.0 & 0.5 & 0.5 & 4.5 \\
\hline East Asia and the Pacific & 4.3 & 1.9 & 1.7 & 2.8 & -0.3 & -0.1 & 7.1 \\
\hline Europe and Central Asia & 4.0 & 1.6 & 1.3 & 2.8 & -0.3 & 0.0 & 4.1 \\
\hline Latin America and the Caribbean & 3.8 & 1.5 & 1.1 & 2.7 & -0.4 & 0.1 & 6.7 \\
\hline Middle East and North Africa & 4.2 & 1.7 & 1.1 & 2.6 & 0.0 & 0.6 & 6.0 \\
\hline South Asia & 4.3 & 1.7 & 1.6 & 3.0 & -0.4 & -0.3 & 7.9 \\
\hline Sub-Saharan Africa & 2.6 & 0.8 & 0.5 & 2.6 & -0.8 & -0.5 & 4.1 \\
\hline Standard deviation (across regions) & 1.0 & 0.5 & 0.6 & 0.2 & 0.4 & 0.4 & 1.5 \\
\hline
\end{tabular}

Source: Author's calculations.

1/PIMI adjusted variables

2/Excludes oil output

\section{Although physical capital accumulation explains most of the variation in output,} its contribution has been small. The bottom half of Table 1 reports the standard deviation of the contribution of inputs and productivity to output - compared to education, differences in physical capital and productivity are the largest across countries. Physical capital accumulation and contribution to output has been small in MENA compared to Latin America and the Caribbean, and Europe and Central Asia, both regions have spent less but accumulated more capital stock per worker. Within MENA countries, we see that although public investment in Jordan has been higher than in other non-oil countries (such as Tunisia), 
it has not resulted in higher physical capital accumulation. ${ }^{6}$ Jordan spent about 4 percent of GDP for a physical capital per worker contribution of 1.2, while Tunisia spent 2.3 percent of GDP for a contribution of 1.4. A similar finding, though more pronounced, emerges with oil exporters - countries like Algeria have spent on average 12 percent of GDP for a physical capital per worker contribution of only 2.3. In part this reflects high population growth in MENA which would have required more public investment for the capital stock to increase as elsewhere, but also is an indication that high public investment spending in the region has not translated into productive capital accumulation.

\section{Human capital contributions to output per worker are higher than physical} capital contributions. In Jordan education contributes nearly twice as much as physical capital - reflecting increases in the years of schooling from 3 years in 1970 to 9 years by 2008. These substantial efforts to improve education are reflected in the rest of the MENA region which has seen similar increases in their educational attainment. Physical capital contributions have lagged, but not because of low public investment spending, but rather because spending has not translated into capital accumulation.

\section{Policy Implications}

10. From a regional perspective capital stock accumulation in MENA has come at a high cost. Public investment spending in MENA has been much higher than in other countries, but has engendered similar levels of capital accumulation and has not led to commensurate output increases. This suggests a focus on public investment with less regard to implementing policies that promote efficiency. Productivity levels are also disappointing, reflecting the variety of shocks the region has experienced, but also the need to improve the efficiency with which resources are used.

\section{Increasing capital spending in Jordan could have high returns, given its} relatively low stock of capital per worker and relatively efficient investment process. To benefit fully from increased capital spending, however, Jordan should look to further improve its efficiency of investment, specifically by enhancing the final stage of the investment process, that of project evaluation and appraisal.

\footnotetext{
${ }^{6}$ Traditional estimates of public capital stock to GDP and PIMI adjusted capital stocks diverge, likely due to inefficiencies in public investment management in Jordan.
} 


\section{References}

Barro, R. and X. Sala-i-Martin, 2004, Economic Growth, MIT Press: Cambridge, MA.

Dabla-Norris, E., J. Brumby, A. Kyobe, and C. Papageorgiou, 2010, “Investing in Public Efficiency," IMF Working Paper 11/37 (Washington: International Monetary Fund).

Gupta, S., A. Kangur, C. Papageorgiou, and A. Wane, 2011, "Efficiency-Adjusted Public Capital and Growth,” IMF Working Paper 11/217 (Washington: International Monetary Fund).

Hall, R.E., and C.I. Jones, 1999, "Why Do Some Countries Produce So Much More Output Per Worker Than Others?," Quarterly Journal of Economics, Vol. 114, pp. 83-116.

International Monetary Fund, 2011, "Fiscal Implications of Megaprojects and Options to Improve the Fiscal Management of Public-Private Partnerships," Fiscal Affairs Department (FAD) Technical Assistance Report.

Pritchett, L., 2000, “The Tyranny of Concepts: CUDIE (Cumulated, Depreciated, Investment Effort) Is Not Capital,” Policy Research Working Paper Series, World Bank. 